\title{
AN EMPIRICAL ANALYSIS OF THE DETERMINANTS OF BANK PROFITABILITY IN ROMANIA
}

\author{
Angela Roman ${ }^{1}$ \\ Adina Elena Dănulețiu²
}

\begin{abstract}
Our paper aims to investigate the factors that have an influence upon the profitability of Romanian commercial banks, between 2003 and 2011. The results of our study show that Romanian banks' profitability is influenced by both bank-specific factors and changes in the external environment. In the case of bank-specific factors, the results of our study reflect that bank profitability is significantly influenced by asset quality, management quality and banking liquidity. Among external factors, it turns out that banking concentration and economic growth rate have an important impact on bank profitability.
\end{abstract}

Keywords: commercial banks; profitability, bank specific factors, industry-specific variables, macroeconomic variables

JEL Codes: G21, C23, M20

\section{Introduction}

The analysis of the main factors that impact on bank profitability has drawn the attention of the decision makers and of the researchers as the banking sector is of vital importance for developing a national economy and establishing the financial stability. Moreover, the serious implications of the recent international financial crisis on the banking sector bring back to the center of attention the evaluation of the bank profitability determinants. Knowing them represents an interest not only to the regulatory and supervisory authorities, bank managers, but also to their clients.

In Romania, the financial system is focused on banks, which have a crucial role in financing the real economy and ensuring the financial stability. In this context, ensuring a healthy, stable and highly effective banking sector is of major importance to deal with long term economic growth and economic and financial stability.

In the latest years, which preceded the current world economic crisis, amid significant structural, institutional and legislative transformations, the Romanian banking sector has registered an extremely rapid growth, with major impact upon bank profitability and efficiency. Following a highly accelerated dynamic of loans, especially to households, a diversity of banking operations, a range of banking products and services, the banks have recorded a growing income, with positive and significant impact upon the profitability indicators. In the context of the recent global economic crisis, the serious decrease of both supply and demand for loans, the significant deterioration of credit portfolio quality, the banking risk amplifications or the provision increase have considerably affected the Romanian banks profitability.

In this context, by using a balanced bank level panel data, the objective of our research is to stress out the impact that bank-specific, industry-specific and macroeconomic factors have upon the profitability of the commercial banks that operate in Romania.

\footnotetext{
${ }^{1}$ „Alexandru Ioan Cuza” University of Iasi, Romania, e-mail: aboariu@uaic.ro

„21 Decembrie 1918” University of Alba Iulia, Romania, e-mail: adina.danuletiu@gmail.com
} 
Our paper is based on the studies of Dietrich and Wanzenried (2010), Acaravci and $\square$ alim (2013), Naceur (2003). On the basis of these studies and on other studies focused on bank profitability determinants, we used an econometric model based on an analysis of multiple linear regressions that allowed us to investigate the relationship between bank profitability and some internal and external determinants.

In order to reach our goal, the paper is structured as it follows: section two is dedicated to literature review; section three briefly describes the variables included in our analysis; section four reflects the data and the methodology used; section five highlights the results of our investigation, and section six reflects the conclusions.

\section{Review of existing literature}

The analysis of the literature emphasizes the existence of a significant number of empirical studies that focused on investigating the factors that impact the bank profitability.

Naceur (2003) evaluates the influence of bank's characteristics, financial structure and macroeconomic indicators on bank's net interest margins and profitability for a sample of 10 deposit banks from Tunisia, between 1980 and 2000. The results of the study show that a high net interest margin and profitability are associated to the banks that possess a relatively high amount of capital and with large overheads. Considering the effect of the macroeconomic indicators, the paper shows that the inflation rate and the economic growth rate have an impact upon bank's interest margins and profitability. Regarding the impact of financial structure indicators, the results of the empirical analysis show that the stock market development has a positive effect upon the bank profitability.

Preoccupied with the recognition of the banking performance determinants, Athanasoglou et al. (2006) analyze the impact of bank-specific, industry-related and macroeconomic variables on bank profitability in seven countries (including Romania) of the South Eastern European Region, between 1998 and 2002. As being anticipated the results of the study show that, except for liquidity, all bank-specific determinants significantly affect the bank profitability. The study also accentuates that the changes in the structure of the banking sector and the macroeconomic environment have got a direct impact upon the banking performance.

Staikouras, Mamatzakis and Koutsomanoli-Filippaki (2007) investigate the empirical relationship between the operational performance and bank, market and country specific characteristics, in the case the banks from seven countries (including Romania) and the South Eastern European Region, between 1998 and 2003. The empirical results show that, for the analyzed period, the operating expenses decreased in all banking sectors in the sample, except those from the FYR of Macedonia and Serbia \& Montenegro, which would show that, in average, the banks improved their operating performance.

Athanasoglou et al. (2008) analyze the impact of the bank-specific, industry-specific and macroeconomic determinants on the bank profitability, for a sample of Greek banks that operated from 1985 to 2001. The results of the empirical study show that among the analyzed factors, the industry-specific one would not significantly influence the Greek banks' profitability, although the Greek banking sector evolved considerably in the given period.

Sufian (2010) analyzes the determinants of the bank profitability in Korea between 1994 and 2008, and the results of his study show that the banks presenting a lower credit risk have the tendency to register higher profitability levels. Regarding the impact of the macroeconomic and banking industry specific factors, the study shows that the inflation has a significant pro-cyclical impact, the GDP has a counter-cyclical influence, and the banking sector concentration has a negative impact upon the profitability of the banks, as well.

The major negative implications of the recent financial crises upon the financial institutions made Dietrich and Wanzenried (2010) focus their attention on investigating the main determinants of the profitability for the Swiss banking market. The empirical analysis performed on a sample of 
453 commercial banks in Switzerland, from 1999 to 2008, highlights the existence of some significant differences in the banks' profitability. The results of the study show, on the one hand, that the banks which are more capitalized are also more profitable. On the other hand, regarding the crisis impact, the authors bring out that the cost-income ratio had a significant impact on the return on assets only for the period before the crisis, while during the crisis a negative impact on the profitability was exerted by the loan loss provisions relative to total loans.

Recently, Trujillo-Ponce (2013) empirically analyze the determinant factors of the bank profitability in Spain, between 1999-2009, and on the other hand the differences between the performances of the commercial banks and the savings banks. The results show, in particular, that better capitalized banks have a higher level of return on assets. Regarding the exogenous variables, the study shows a positive relationship between the market concentration and the profitability of the Spanish banks, and also the importance of the economic cycle for the profitability of the banking sector. Regarding the performances of the commercial banks and the savings banks, the study shows some important qualitative differences, in favor of the commercial banks.

The literature review reflects the existence of some gaps in knowing the determining factors of the bank profitability for the banks that operate in Romania, the existence of a relatively reduced number of studies being noticed, especially of recent date. Thus, our paper contributes to the literature by providing empirical evidence regarding some key factors that influence the profitability of the commercial banks from Romania.

\section{Selecting the variables and the hypothesis}

The bank profitability is reflected in the majority of empirical studies by two major rates, namely the Return on Average Assets (ROAA: the net income to average total assets) and Return on Average Equity (ROAE: the net income to average equity). The two profitability measures are used alternatively as a dependent variable in our study.

According to the literature, the independent variables are represented by the bank-specific factors and by the external ones (macroeconomic and financial sector specific) that can influence bank profitability.

Based on the empirical studies focused on evaluating bank's profitability, the determinants of bank profitability can be divided in two groups, respectively internal determinants or bank specific (namely capital adequacy, asset quality, management quality, liquidity and bank size) and external determinants, respectively macroeconomics factors and bank industry specific (especially the banking concentration, the Herfindahl-Hirschman-Index, stock market capitalization, GDP growth and inflation).

In our analysis, we have used the following variables as determinants factors:

Capital adequacy expressed in the majority of the studies by the ratio of total equity to total asset (EA). This indicator reflects the financial soundness of a bank, respectively its capacity of covering the eventual losses that can arise when a risk appears. Regarding the relationship between capital adequacy and bank profitability, the results of the empirical studies are mixed, therefore it cannot be anticipated.

The ratio of nonperforming loans to total loans (NLP) is a variable proxy for the credit risk, and, also, it reflects the banks' asset quality, respectively the soundness of credit portfolio. A high level of this indicator meaning a significant deterioration of the banks' assets leads to a decrease in bank profitability.

The management quality is expressed in our analysis by the non-interest expense over total assets ratio (NIEA). An increase in the level of this rate leads to a decrease of bank's profitability, thus we expect a negative relationship between these variables.

The ratio of loans to total assets (LA) indicates which percentage of banking assets are represented by loans. The relationship between this indicator and bank profitability is uncertain; fact proven by the empirical studies that provide mixed results. Therefore, an increase in the level 
of this indicator can state a deterioration of the soundness of loan portfolio, with a negative impact on profitability. However, when the increase in bank loans triggers an increase in interest incomes, we expect a positive impact on profitability.

Liquidity $(L)$ is of major importance for a bank and evaluates the operational performance of the banks, reflecting the capacity of a bank to pay the debts on a short term and to cope with unexpected withdrawals of depositors. In order to honor these obligations and in general to be able to provide liquidities, the banks must own highly liquid and easy transferable assets. In the case of the banks with less liquid assets there is a high possibility that these institutions will default. In order to measure liquidity our study uses the ratio of liquid assets to total assets (LIQA). Regarding the connection with profitability, we expect a negative relationship since liquid assets produce a low return.

Funding costs (FC) is expressed in our study by the interest expenses to deposits ratio. A decrease of financing cost leads to an increase of bank's profitability.

Income diversification of bank is measured by the non-interest income over total gross revenues (NIIR). An increase of this indicator, as a result of bank activities, leads to an increase of bank's profitability.

Bank size is evaluated in our analysis by the natural logarithm of the total assets of bank (LNTA). The majority of empirical studies reflect mixed results regarding the relationship with the profitability; therefore the impact on bank size is not clear.

In addition to the internal determinants previously mentioned, in our analysis we use external determinants, respectively the industry-specific variables and the macroeconomic variables.

Banking concentration described by the 5-bank concentration ratio (CR5), respectively the weight of top five largest banks in the system to total assets in the system. According to the literature, the impact of this variable on profitability is uncertain.

The ratio stock market capitalization to GDP (MKCGDP) measured as a ratio between the shares at current market price and GDP. The results of the study conducted by Demirguc-Kunt and Huizinga (1998) reflect that the ratio stock market capitalization to GDP is positively linked to the net interest margin, which suggests that a larger stock market allows the banks to obtain higher interest margins, with positive impact upon profitability. This can be due to the complementarity effect between debt and equity financing. On the other side, the above mentioned authors declare that while the stock market develops, the information availability improves, which allows the banks to identify and monitor the potential borrowers. In these conditions, a growth of the volume of business and an increase of the margins can be recorded for banks, with positive impact upon the bank profitability. According to Demirguc-Kunt and Huizinga (1998), Naceur (2003) showed the positive impact upon profitability (expressed by the return on assets) of the ratio stock market capitalization to GDP. On the other hand, other authors (Dietrich and Wanzenried, 2010) consider that an increasing stock market capitalization could indicate an amplification of financial disintermediation. Thus, banks can react by decreasing the interest rate margins that could lead to a decrease in profitability.

Regarding the macroeconomic variables, in our study we use the annual real GDP growth rate (GDP) and the annual inflation rate (INF). The relationship between the first variable and profitability is positive since an increase in the economic activity leads to an amplification of loan demand that leads to an increase in bank's profitability. The impact of inflation upon profitability depends on bank's capacity to anticipate inflation. Thus, when inflation is anticipated, banks will adjust the interest rates, recording a higher increase in income compared to costs, with a positive impact on profitability.

\section{Data and methodology}

The bank specific data that we used in our study were obtained from the unconsolidated financial and annual reports of the banks from our sample and from the Bureau Van Dijk 
Bankscope database. The data regarding the macroeconomic variables were obtained from the annual bulletins of the National Bank of Romania and the data regarding the industry-specific variables were obtained from the World Bank.

The analyzed sample has 15 commercial banks that operate in Romania and that hold together $78.10 \%$ of the total bank assets. We chose to analyze only the commercial banks because most of the credit institutions that operate in Romania enter this category. Furthermore, we have selected only commercial banks that have available information between 2003 and 2011. Because all the 15 banks from our sample are observed during 2003-2011, our study uses a balanced panel dataset.

Our paper uses panel data due to the advantage that it has. It helps to study the behaviour of each bank over time and across space (Baltagi, 2005; Gurajati, 2003). A multiple linear regression model was issued to determine the relative importance (sensitivity) of each explanatory variable in affecting the performance of bank.

The general linear regression model is:

$$
\mathrm{Y}_{\mathrm{it}}=\mathrm{c}+\beta_{\mathrm{i}} \mathrm{X}_{\mathrm{it}}+\mu_{\mathrm{it}}
$$

where: Yit- dependent variable observed for $\mathrm{i}$-th bank at time $\mathrm{t}$; $\mathrm{X}$ - one independent variable; $\beta$ - the coefficient for explanatory variables; $\mathrm{i}=2 \ldots \mathrm{N} ; \mathrm{c}$ is a constant term; $\mu$ - error term of the model.

Starting from the general model and taking into account the selected variables, the empirical model used in our study is:

$$
\begin{aligned}
\operatorname{ROAA}_{\mathrm{it}}\left(\mathrm{ROAE}_{\mathrm{it}}\right)= & \mathrm{c}+\beta_{1} \mathrm{EA}_{\mathrm{it}}+\beta_{2} \mathrm{NPL}_{\mathrm{it}}+\beta_{3} \mathrm{NIEA}_{\mathrm{it}}+\beta_{4} \mathrm{LA}_{\mathrm{it}}+\beta_{5} \mathrm{LIQA}_{\mathrm{it}}+\beta_{6} \mathrm{FC}_{\mathrm{it}}+\beta_{7} \mathrm{NIR}_{\mathrm{it}}+ \\
& +\beta_{8} \mathrm{LNTA}_{\mathrm{it}}+\beta_{9} \mathrm{CRT}_{\mathrm{it}}+\beta_{10} \mathrm{MKGDP}_{\mathrm{it}}+\beta_{11} \mathrm{GDP}_{\mathrm{it}}+\beta_{12} \mathrm{INF}_{\mathrm{it}}
\end{aligned}
$$

Equation (2) is used alternatively for the two main indicators of bank profitability, respectively Return on Average Assets (ROAA) and Return on Average Equity (ROAE).

Descriptive statistics of the variables used in our analysis

\begin{tabular}{|c|c|c|c|c|c|}
\hline Variables & No. obs. & Mean & Max. & Min. & Std. Dev. \\
\hline ROAA & 135 & 0.7860 & 3.9800 & -10.9400 & 2.0699 \\
\hline ROAE & 135 & 5.0688 & 42.5700 & -256.5400 & 35.0988 \\
\hline EA & 135 & 11.3463 & 33.9800 & 4.2200 & 4.2838 \\
\hline NPL & 135 & 7.1574 & 45.4500 & 0.0200 & 7.4191 \\
\hline NIEA & 135 & 5.5984 & 14.0100 & 1.7800 & 2.4460 \\
\hline LA & 135 & 55.7458 & 77.9900 & 12.4300 & 12.4911 \\
\hline LIQA & 135 & 34.4384 & 109.3200 & 1.9200 & 18.9532 \\
\hline FC & 135 & 6.6106 & 29.6300 & 1.5600 & 3.3895 \\
\hline NIIR & 135 & 36.4333 & 70.8100 & -4.0000 & 14.4282 \\
\hline LNTA & 135 & 8.6724 & 11.2500 & 4.6700 & 1.3673 \\
\hline CR5 & 135 & 81.6200 & 85.5800 & 77.0900 & 3.0299 \\
\hline MKCGDP & 135 & 16.4811 & 24.2200 & 8.4600 & 4.6343 \\
\hline GDP & 135 & 3.7667 & 8.5000 & -6.6000 & 4.6630 \\
\hline INF & 135 & 8.1022 & 15.3000 & 4.8400 & 3.2752 \\
\hline
\end{tabular}

Source: author's calculations

The major determinants (independent variables) were the ratio of total equity to total asset (EA), the ratio of non-performing loans to total loans (NLP), non-interest expense over total assets ratio (NIEA), the ratio of loans to total assets (LA), the ratio of liquid assets to total assets (LIQA), 
funding costs (FC), non-interest income over total gross revenues (NIIR), the natural logarithm of the accounting value of the total assets of bank (LNTA), the 5-bank concentration ratio (CR5), the ratio stock market capitalization to GDP (MKCGDP), annual real GDP growth rate (GDP) and the inflation (INF). All variables are in percents.

The summary statistics for the variables used in the analysis are presented in table no. 1.

\section{Empirical Results}

The following diagnostic test were carried out to ensure that data suits basic assumptions of classical linear regression model: multicollinearity and heteroscedasticity

To check for multicollinearity we were used the most widely-used diagnostic for multicollinearity, the variance inflation factor (VIF) and correlation coefficient.

The VIF may be calculated for each predictor by doing a linear regression of that predictor on all the other predictors, and then obtaining the $R^{2}$ from that regression. The VIF is just $1 /\left(1-R^{2}\right)$. It's called the variance inflation factor because it estimates how much the variance of a coefficient is "inflated" because of linear dependence with other predictors.

About interpretation of VIF there are many opinions such as: "Neter et al. (1989: 409) state "A maximum VIF value in excess of 10 is often taken as an indication that multi-collinearity may be unduly influencing the least square estimates". Hair et al. (1995) suggest that a VIF of less than 10 are indicative of inconsequential collinearity. Marquardt (1970) uses a VIF greater than 10 as a guideline for serious multi-collinearity. Mason et al. (1989) cite a VIF of greater than 10 as reason for concern. The STATA manual (StataCorp 1997: 390) notes: "However, most analysts rely on informal rules of thumb applied to VIF (see Chaterjee and Price 1991). According to these rules, there is evidence of multi-collinearity if 1 . The largest VIF is greater than 10 (some chose the more conservative threshold value of 30). 2. The mean of all of the VIF's is considerably larger than 1." Kennedy (1992:183) states that "for standardized data VIF $i>10$ indicates harmful collinearity"(O'Brien, 2007).

\section{Variance Inflation Factor}

\begin{tabular}{|c|c|c|}
\hline Variable & VIF & 1/VIF \\
\hline INF & 10,76 & 0.092979 \\
\hline MKCGDP & 5.96 & 0.167802 \\
\hline CR5 & 3.35 & 0.298843 \\
\hline LNTA & 3.17 & 0.315138 \\
\hline NIEA & 2.76 & 0.362282 \\
\hline GDP & 2.54 & 0.393171 \\
\hline LIQA & 2.29 & 0.436049 \\
\hline FC & 2.11 & 0.473564 \\
\hline LA & 2.02 & 0.494627 \\
\hline NPL & 1.63 & 0.612138 \\
\hline EA & 1.57 & 0.638627 \\
\hline NIIR & 1.22 & 0.818637 \\
\hline Mean VIF & 3.28 & \\
\hline Source: authors &
\end{tabular}

Source: authors calculations

Table no. 2

As can be seen from table no. 2, variable INF is more than 10 and the rest of variables look ok. In this case, as Paul Allison said, we can safely ignore multicollinearity because the variable with high VIFs is control variable, and the variables of interest do not have high VIFs. "Here's the thing about multicollinearity: it's only a problem for the variables that are collinear. It increases the standard errors of their coefficients, and it may make those coefficients unstable in several ways. But as long as the collinear variables are only used as control variables, and they are not collinear 
with variables of interest, there's no problem. The coefficients of the variables of interest are not affected, and the performance of the control variables as controls is not impaired".

Table no. 3 presents the correlation matrix for all variables in the model. Numbers are Pearson correlation coefficients: go from -1 to 1 . Closer to 1 means strong correlation. A negative value indicates an inverse relationship (roughly, when one goes up other goes down). Correlation above 0.8 between independent variables indicates the existence of the problem of multicollinearity (Gurajati, 2007). There is not a serious multicolinearity problem as can be seen from table no 3 . All the correlation coefficients between the independent variables were less than 0.8 .

Further, we explore the panel-data model heterogeneity, testing both fixed and random effect. F-test is performed as support for choice between OLS models and fixed-effects models, while Hausman test decides between fixed and random effects models and Breusch and Pagan Lagrangian multiplier test (LM) decides between random effects model and OLS.

The result from table no. 4 shows that we use random effect in our models because in both regressions for ROAA and ROAE $\mathrm{p}>0.05$

The Brusch and Pagan Lagrangian multiplier test for random effects is presented in table no. 5. The null hypothesis in LM test is that variances across banks are zero. This is no significant difference across units (i.e. no panel effect). The results presented in table no. 5 conclude that random effects is appropriate because in both cases $\mathrm{p}=0.0000$.

The other assumption of the model was heteroscedasticity. To avoid the problem of heteroscedasticity of the disturbance term we used in the analysis the "robust"option in both fixed and random effects models.

The empirical results of the panel regression are presented in table no. 6 for ROAA and table no.7 for ROAE.

The coefficient of the ratio of total equity to total asset (EA) is positive, expressing a direct relationship with the bank's profitability, similar to the results of Goddard et al. (2004), Athanasoglou et al. (2008), Dietrich and Wanzenried (2010) and Trujillo-Ponce (2013). Furthermore, the results of our study show that the relationship is not statistically significant, in both profitability equations.

The quality of the assets expressed by NPL is an important determinant of the banking profitability. The coefficient is statistically significant at $1 \%$ significance level and, as it was expected, indicates a negative rapport to the banking profitability. This shows that banks with a high credit risk present more reduced profitability levels. In the current crisis, the Romanian banking sector recorded a significant increase in the rate of non-performing loans as a result of the deteriorating economic environment and hence the financial situation of banks' clients, and new accounting rules required by the IFRS, namely the recognition of overdue claims previously entered in off-balance-sheet accounts. However, it is noted that the Romanian banks are well capitalized and can absorb potential losses resulting from the activity.

In order to reduce credit risk, the National Bank of Romania has adopted a series of measures among which the adequate provisioning of expected losses and setting more stringent criteria when granting consumer loans, particularly foreign currency-denominated lending. 


\section{Correlation matrix for all variables in the model}

Table no. 3

\begin{tabular}{|c|c|c|c|c|c|c|c|c|c|c|c|c|c|}
\hline & roaa & ea & npl & niea & la & liqa & fc & niir & Inta & gdp & inf & Cr5 & mkcgdp \\
\hline Roaa & 1.0000 & & & & & & & & & & & & \\
\hline Ea & $\begin{array}{l}0.1207 \\
0.1631\end{array}$ & 1.0000 & & & & & & & & & & & \\
\hline Npl & $\begin{array}{c}-0.4568 * * * \\
0.0000\end{array}$ & $\begin{array}{c}-0.0895 \\
0.3017\end{array}$ & 1.0000 & & & & & & & & & & \\
\hline Niea & $\begin{array}{c}-0.1937 * * \\
0.0244\end{array}$ & $\begin{array}{c}0.4589 * * * \\
0.0000\end{array}$ & $\begin{array}{c}-0.1570^{*} \\
0.0689\end{array}$ & 1.0000 & & & & & & & & & \\
\hline La & $\begin{array}{l}0.0792 \\
0.3613\end{array}$ & $\begin{array}{c}-0.0188 \\
0.8286\end{array}$ & $\begin{array}{c}-0.2551 * * * \\
0.0028\end{array}$ & $\begin{array}{c}-0.0132 \\
0.8793\end{array}$ & 1.0000 & & & & & & & & \\
\hline Liqa & $\begin{array}{c}-0.3210^{* * * *} \\
0.0001\end{array}$ & $\begin{array}{c}-0.2788 * * * * \\
0.0011\end{array}$ & $\begin{array}{c}0.4813^{* * * *} \\
0.0000\end{array}$ & $\begin{array}{c}-0.1878 * * \\
0.0292\end{array}$ & $\begin{array}{c}-0.5479 * * * \\
0.0000\end{array}$ & 1.0000 & & & & & & & \\
\hline Fc & $\begin{array}{c}-0.2396 * * * \\
0.0051\end{array}$ & $\begin{array}{c}0.4742 * * * \\
0.0000\end{array}$ & $\begin{array}{c}-0.0867 \\
0.3173\end{array}$ & $\begin{array}{c}0.5102 * * * \\
0.0000\end{array}$ & $\begin{array}{l}0.1027 \\
0.2360\end{array}$ & $\begin{array}{c}-0.2767 * * * \\
0.0012\end{array}$ & 1.0000 & & & & & & \\
\hline Niir & $\begin{array}{l}0.0849 \\
0.3274\end{array}$ & $\begin{array}{c}-0.1508 \\
0.0807\end{array}$ & $\begin{array}{l}0.0024 \\
0.9777\end{array}$ & $\begin{array}{c}-0.1341 \\
0.1211\end{array}$ & $\begin{array}{c}-0.1133 \\
0.1909\end{array}$ & $\begin{array}{l}0.1237 \\
0.1528\end{array}$ & $\begin{array}{c}-0.3191 * * * \\
0.0002\end{array}$ & 1.0000 & & & & & \\
\hline Lnta & $\begin{array}{c}0.2997 * * * \\
0.0004\end{array}$ & $\begin{array}{c}-0.4383 * * * \\
0.0000\end{array}$ & $\begin{array}{l}0.1128 \\
0.1927\end{array}$ & $\begin{array}{c}-0.7713 * * * \\
0.0000\end{array}$ & $\begin{array}{l}0.0578 \\
0.5057\end{array}$ & $\begin{array}{l}0.0897 \\
0.3011\end{array}$ & $\begin{array}{c}-0.5734 * * * \\
0.0000\end{array}$ & $\begin{array}{c}0.2690^{* * *} * \\
0.0016\end{array}$ & 1.0000 & & & & \\
\hline Gdp & $\begin{array}{c}0.2818 * * * \\
0.0009\end{array}$ & $\begin{array}{c}0.1490^{*} \\
0.0847\end{array}$ & $\begin{array}{c}-0.3949 * * * \\
0.0000\end{array}$ & $\begin{array}{c}0.2591 * * * \\
0.0024\end{array}$ & $\begin{array}{c}-0.0824 \\
0.3418\end{array}$ & $\begin{array}{c}-0.2789 * * * \\
0.0011\end{array}$ & $\begin{array}{c}-0.0059 \\
0.9460\end{array}$ & $\begin{array}{c}-0.0279 \\
0.7478\end{array}$ & $\begin{array}{c}-0.2462 * * * \\
0.0040\end{array}$ & 1.0000 & & & \\
\hline Inf & $\begin{array}{c}0.1483 * \\
0.0861\end{array}$ & $\begin{array}{c}0.4070^{* * * *} \\
0.0000\end{array}$ & $\begin{array}{c}-0.2054 * * \\
0.0168\end{array}$ & $\begin{array}{c}0.4428 * * * \\
0.0000\end{array}$ & $\begin{array}{c}-0.2526^{* * *} * \\
0.0031\end{array}$ & $\begin{array}{c}-0.1620^{*} \\
0.0605\end{array}$ & $\begin{array}{c}0.3964 * * * \\
0.0000\end{array}$ & $\begin{array}{c}-0.1777 * * \\
0.0392\end{array}$ & $\begin{array}{c}-0.4670^{* * *} \\
0.0000\end{array}$ & $\begin{array}{c}0.3856^{* * * *} \\
0.0000\end{array}$ & 1.0000 & & \\
\hline Cr5 & $\begin{array}{c}-0.0697 \\
0.4217\end{array}$ & $\begin{array}{c}-0.3835 * * * \\
0.0000\end{array}$ & $\begin{array}{c}-0.0245 \\
0.7783\end{array}$ & $\begin{array}{c}-0.3830 \text { *** } \\
0.0000\end{array}$ & $\begin{array}{c}0.3577^{* * *} \\
0.0000\end{array}$ & $\begin{array}{l}0.0155 \\
0.8580\end{array}$ & $\begin{array}{c}-0.2806^{* * * *} \\
0.0010\end{array}$ & $\begin{array}{c}0.2146^{* *} \\
0.0124\end{array}$ & $\begin{array}{c}0.4106^{* * * *} \\
0.0000\end{array}$ & $\begin{array}{c}-0.1749 * * \\
0.0424\end{array}$ & $\begin{array}{c}-0.7821 * * * \\
0.0000\end{array}$ & 1.0000 & \\
\hline mkcgdp & $\begin{array}{c}-0.0135 \\
0.8766\end{array}$ & $\begin{array}{c}-0.3063 * * * \\
0.0003\end{array}$ & $\begin{array}{c}-0.0694 \\
0.4237\end{array}$ & $\begin{array}{c}-0.2630 \text { *** } \\
0.0021\end{array}$ & $\begin{array}{c}0.1818^{* *} \\
0.0349\end{array}$ & $\begin{array}{c}-0.0034 \\
0.9687\end{array}$ & $\begin{array}{c}-0.3861 * * * \\
0.0000\end{array}$ & $\begin{array}{c}0.1704 * * \\
0.0482\end{array}$ & $\begin{array}{c}0.2952 * * * \\
0.0005\end{array}$ & $\begin{array}{l}0.0792 \\
0.3611\end{array}$ & $\begin{array}{c}-0.7966^{* * *} * \\
0.0000\end{array}$ & $\begin{array}{c}0.6549 * * * \\
0.0000\end{array}$ & 1.0000 \\
\hline
\end{tabular}

Note: $* * *, * *, *$, indicates significance at $1 \%, 5 \%$ and $10 \%$ levels.

Source: authors calculations 


\section{Result of Hausman test}

Table no. 4

Hausman test for ROAA

\begin{tabular}{|c|c|c|c|c|}
\hline & \multicolumn{2}{|c|}{ Coefficients } & \multirow[b]{2}{*}{$\begin{array}{c}\text { (b-B) } \\
\text { difference }\end{array}$} & \multirow[b]{2}{*}{$\begin{array}{c}\operatorname{Sqrt}\left(\operatorname{diag}\left(\mathbf{V} \_b-v \_B\right)\right) \\
\text { S.E. }\end{array}$} \\
\hline & $\begin{array}{l}\text { (b) } \\
\text { fixed }\end{array}$ & $\begin{array}{c}\text { (B) } \\
\text { random }\end{array}$ & & \\
\hline $\mathrm{Ea}$ & .0957123 & .1076582 & -.0119459 & .0114476 \\
\hline $\mathrm{Npl}$ & -.1281175 & -.1252043 & -.0029133 & .0084868 \\
\hline $\mathrm{La}$ & -.2326119 & -.1991803 & -.0334315 & .0765346 \\
\hline Liqa & -.0117537 & -.0099777 & -.001776 & .0076691 \\
\hline $\mathrm{Fc}$ & -.0349781 & -.0281937 & -.0067844 & .004675 \\
\hline Niir & -.0192004 & -.1283021 & .0256013 & .0206434 \\
\hline lnta & .7745134 & -.0112486 & -.0079518 & .0073987 \\
\hline gdp & .0630799 & .5324791 & .2420343 & .3460632 \\
\hline inf & -.0033719 & .0637409 & -.000661 & \\
\hline $\mathrm{Cr} 5$ & -.1454041 & -.0389069 & .035535 & .0644635 \\
\hline mkcgdp & -.0511098 & -.1184486 & -.0269555 & .0249743 \\
\hline & & -.065507 & 0.143972 & .0180187 \\
\hline
\end{tabular}

$\mathrm{B}=$ inconsistent under $\mathrm{Ha}$, efficient under $\mathrm{Ho}$; obtained from xtreg

Test : Ho: difference in coefficients not systematic

$$
\text { Chi2 }(12)=(b-B)^{\prime}\left[\left(v_{-} \text {b-v_B }\right)^{\wedge}(-1)\right](b-B)=6.81
$$$$
\text { Prob }>\text { chi } 2=0.8701
$$

(v_b-v_B) is not positive definite

Source: authors calculations
Hausman test for ROAE

\begin{tabular}{|c|c|c|c|c|}
\hline & \multicolumn{2}{|c|}{ Coefficients } & \multirow[b]{2}{*}{$\begin{array}{c}\text { (b-B) } \\
\text { difference }\end{array}$} & \multirow[b]{2}{*}{$\begin{array}{c}\operatorname{Sqrt}\left(\operatorname{diag}\left(\mathbf{V} \_b-\mathbf{b} \_B\right)\right) \\
\text { S.E. }\end{array}$} \\
\hline & $\begin{array}{l}\text { (b) } \\
\text { fixed }\end{array}$ & $\begin{array}{c}\text { (B) } \\
\text { Random }\end{array}$ & & \\
\hline $\mathrm{Ea}$ & 2.297529 & 2.321318 & -0.237895 & .1666956 \\
\hline $\mathrm{Npl}$ & -2.404063 & -2.388491 & -.0155723 & .1250111 \\
\hline $\mathrm{La}$ & -7.777912 & -6.715935 & -1.061977 & 1.199751 \\
\hline Liqa & .0237239 & .0417129 & -.017989 & .1159953 \\
\hline $\mathrm{Fc}$ & -.3331646 & -.2300056 & -.103159 & .0710453 \\
\hline Niir & -.4554955 & -.7378481 & .2823526 & .3091112 \\
\hline lnta & -.3667125 & -.2838134 & -082899 & .1155633 \\
\hline gdp & 16.90269 & 8.231389 & 8.671301 & 5.67194 \\
\hline inf & 2.923627 & .5934661 & -0.239329 & 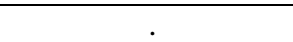 \\
\hline $\mathrm{Cr} 5$ & 2.497996 & .9741933 & 1.949433 & 1.033794 \\
\hline mkcgdp & -5786473 & -1.766674 & -.73102 & .3737731 \\
\hline & & -.0537474 & .6323946 & .2683787 \\
\hline
\end{tabular}

$\mathrm{B}=$ inconsistent under $\mathrm{Ha}$, efficient under $\mathrm{Ho}$; obtained from xtreg

Test : Ho: difference in coefficients not systematic

Chi2 $(12)=(\text { b-B })^{\prime}\left[\left(v_{-} \text {b-v_B }\right)^{\wedge}(-1)\right](b-B)=8.53$

Prob $>$ chi $2=0.7426$

(v_b-v_B) is not positive definite 
Table no. 5

Brusch and Pagan Lagrangian multiplier test for random effects

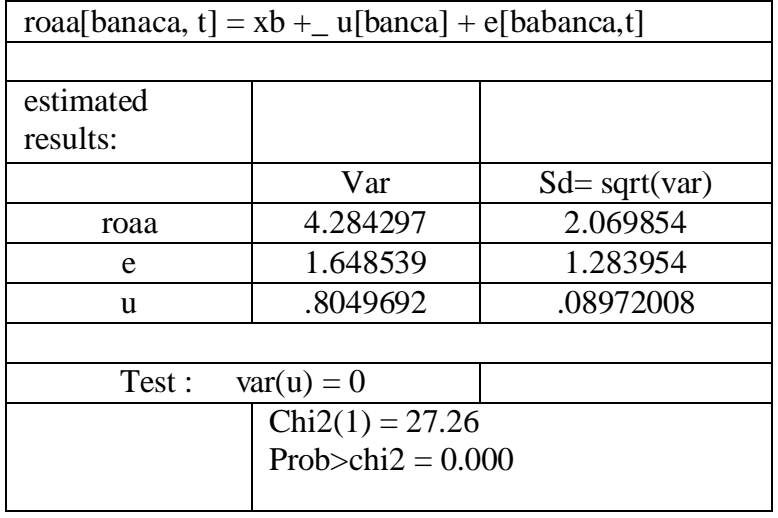

\begin{tabular}{|c|c|c|}
\hline \multicolumn{3}{|l|}{ estimated results: } \\
\hline & Var & $\mathrm{Sd}=\operatorname{sqrt}(\mathrm{var})$ \\
\hline roae & 1231.928 & 35.09883 \\
\hline $\mathrm{e}$ & 471.9809 & 21.72512 \\
\hline $\mathrm{u}$ & 282.4049 & 16.80491 \\
\hline \multicolumn{3}{|c|}{ Test : $\quad \operatorname{var}(\mathrm{u})=0$} \\
\hline & \multicolumn{2}{|c|}{$\begin{array}{l}\text { Chi2 }(1)=24.76 \\
\text { Prob }>\text { chi } 2=0.000\end{array}$} \\
\hline
\end{tabular}

Source: author's calculations

The impact of the management quality is expressed in our model by the NIEA variable. In both profitability equations, the estimated coefficient is statistically significant at $5 \%$ significance level and reflects, as expected, a negative rapport with the profitability. Over the period analyzed is noted that the indicator NIEA, for the Romanian banking sector, has registered a decrease. So if in the pre-crisis decline was driven by banks' ability to expand their businesses in a much faster compared to their costs in the context of international crisis started, reducing the indicator was due to the restructuring of the bank branch network, but and reducing the number of employees.

The coefficient of the ratio of loans to total assets is negative, but insignificant in both profitability equations, respectively, the impact upon the profitability is insignificant. Our results are in accordance with those obtained by Demirgüç-Kunt and Huizinga (2000). As we mentioned, the impact of this variable upon the profitability is unpredictable. Thus, a high value of the indicator could also mean a possible deterioration of the bank assets' quality with a negative effect upon profitability. On the other hand, a high value of the indicator could mean an increase of the credit risk exposure that must be compensated by higher returns that will lead to improved profitability. Our results can be explained by the fact that, at the level of the analyzed banks, in the years before the crisis, the value of the indicator was high and determined an increase of the banks' income, with positive impact upon the profitability. Profitability of banks is affected by the loan losses provisions, which express the banks assets' quality deterioration and in the recent years it is essential that banks efficiently manage the loan loss provisioning processes (Socol, 2011). However, in times of crisis, the banks analyzed an important increase of the nonperforming loans and of the loan loss reserves, which had a negative impact upon the profitability. Overall, the compensation of the two effects results in a negative but statistically insignificant impact.

In the case of liquidity, the obtained results underline a statistically significant rapport at $1 \%$ significance level, and the coefficient is negative, as expected, in both profitability expressing equations. This shows that an increase of the bank's liquidity leads towards a decrease of the profitability. In the context of deteriorating real economy in recent years, banks in Romania have increased their holdings of government securities and increased competition to attract deposits from customers, which led to improved liquidity. In the case of the Romanian banking sector an important role in the improvement of the liquidity has been played by the commitment of the parent banks of the nine largest banking institutions from Romania to maintain their group exposure to this market, the financial agreement with the IMF, the NBR policy of diminishing the mandatory minimal reserves and also the legislative changes made by the NBR in order to adequately manage the liquidity of the banking sector. 
Empirical results of panel regression for ROAA

\begin{tabular}{|c|c|c|c|c|c|c|c|}
\hline Variables & $\begin{array}{c}(1) \\
\text { ROAA }\end{array}$ & $\begin{array}{c}(2) \\
\text { ROAA }\end{array}$ & $\begin{array}{c}\text { (3) } \\
\text { ROAA }\end{array}$ & $\begin{array}{c}\text { (4) } \\
\text { ROAA }\end{array}$ & $\begin{array}{c}(5) \\
\text { ROAA }\end{array}$ & $\begin{array}{c}(6) \\
\text { ROAA }\end{array}$ & $\begin{array}{c}\text { Expected } \\
\text { sign }\end{array}$ \\
\hline & $\begin{array}{c}\text { OLS } \\
\text { robust }\end{array}$ & $\begin{array}{l}\text { Population } \\
\text { average } \\
\text { estimator, } \\
\text { robust }\end{array}$ & $\begin{array}{c}\text { Between } \\
\text { estimator }\end{array}$ & $\begin{array}{l}\text { Fixed } \\
\text { effects, } \\
\text { robust }\end{array}$ & $\begin{array}{c}\text { GLS } \\
\text { Random } \\
\text { Effect }\end{array}$ & $\begin{array}{c}\text { GLS with } \\
\text { AR, RE }\end{array}$ & \\
\hline EA & $\begin{array}{c}0.131^{*} \\
(0.0669)\end{array}$ & $\begin{array}{c}0.108 \\
(0.0766)\end{array}$ & $\begin{array}{c}-0.108 \\
(0.372)\end{array}$ & $\begin{array}{c}0.0957 \\
(0.0791)\end{array}$ & $\begin{array}{c}0.108 \\
(0.0802)\end{array}$ & $\begin{array}{c}0.0414 \\
(0.0399)\end{array}$ & $+/-$ \\
\hline NPL & $\begin{array}{c}-0.113 * * * \\
(0.0405)\end{array}$ & $\begin{array}{c}-0.125 * * * \\
(0.0460)\end{array}$ & $\begin{array}{l}-0.0390 \\
(0.0999)\end{array}$ & $\begin{array}{l}-0.128 * * \\
(0.0442)\end{array}$ & $\begin{array}{c}-0.125 * * * \\
(0.0481)\end{array}$ & $\begin{array}{c}-0.0874 * * * \\
(0.0236)\end{array}$ & - \\
\hline NIEA & $\begin{array}{l}-0.0952 \\
(0.109)\end{array}$ & $\begin{array}{c}-0.198 \\
(0.177)\end{array}$ & $\begin{array}{c}0.000594 \\
(0.219)\end{array}$ & $\begin{array}{c}-0.233 \\
(0.210)\end{array}$ & $\begin{array}{l}-0.199 \\
(0.186)\end{array}$ & $\begin{array}{c}-0.327 * * \\
(0.130)\end{array}$ & - \\
\hline LA & $\begin{array}{c}-0.00189 \\
(0.0116)\end{array}$ & $\begin{array}{c}-0.00993 \\
(0.0115)\end{array}$ & $\begin{array}{c}0.0480 \\
(0.0490)\end{array}$ & $\begin{array}{c}-0.0118 \\
(0.0143)\end{array}$ & $\begin{array}{c}-0.00998 \\
(0.0121)\end{array}$ & $\begin{array}{l}-0.00554 \\
(0.0172)\end{array}$ & $+/-$ \\
\hline $\begin{array}{l}\text { LIQA } \\
\end{array}$ & $\begin{array}{c}-0.0152 \\
(0.0114)\end{array}$ & $\begin{array}{c}-0.0281 * * \\
(0.0128)\end{array}$ & $\begin{array}{c}0.0672 \\
(0.0498)\end{array}$ & $\begin{array}{l}-0.0350^{*} \\
(0.0168)\end{array}$ & $\begin{array}{c}-0.0282 * * \\
(0.0135)\end{array}$ & $\begin{array}{c}-0.0280 * * * \\
(0.0103)\end{array}$ & - \\
\hline $\mathrm{FC}$ & $\begin{array}{l}-0.153^{*} \\
(0.0841)\end{array}$ & $\begin{array}{c}-0.129 \\
(0.0859)\end{array}$ & $\begin{array}{c}0.455 \\
(0.515)\end{array}$ & $\begin{array}{c}-0.103 \\
(0.102) \\
\end{array}$ & $\begin{array}{c}-0.128 \\
(0.0902)\end{array}$ & $\begin{array}{l}-0.0295 \\
(0.0547)\end{array}$ & - \\
\hline NIIR & $\begin{array}{l}8.74 \mathrm{e}-05 \\
(0.0110)\end{array}$ & $\begin{array}{c}-0.0111 \\
(0.0144)\end{array}$ & $\begin{array}{c}0.0620 \\
(0.0533)\end{array}$ & $\begin{array}{c}-0.0192 \\
(0.0188)\end{array}$ & $\begin{array}{c}-0.0112 \\
(0.0152)\end{array}$ & $\begin{array}{l}-0.0141 \\
(0.0116)\end{array}$ & + \\
\hline LNTA & $\begin{array}{c}0.561 * * * \\
(0.145)\end{array}$ & $\begin{array}{c}0.531 * * \\
(0.253)\end{array}$ & $\begin{array}{l}1.225^{*} \\
(0.575)\end{array}$ & $\begin{array}{c}0.775 \\
(0.474)\end{array}$ & $\begin{array}{c}0.532 * * \\
(0.267)\end{array}$ & $\begin{array}{c}0.345 \\
(0.283)\end{array}$ & $+/-$ \\
\hline CR5 & $\begin{array}{c}-0.0945 \\
(0.0781)\end{array}$ & $\begin{array}{c}-0.118^{*} \\
(0.0678)\end{array}$ & & $\begin{array}{c}-0.145^{*} \\
(0.0741)\end{array}$ & $\begin{array}{c}-0.118^{*} \\
(0.0710)\end{array}$ & $\begin{array}{c}-0.129 * \\
(0.0667)\end{array}$ & $+/-$ \\
\hline MKCGDP & $\begin{array}{l}-0.0581 \\
(0.0763)\end{array}$ & $\begin{array}{c}-0.0656 \\
(0.0423)\end{array}$ & & $\begin{array}{l}-0.0511 \\
(0.0564)\end{array}$ & $\begin{array}{c}-0.0655 \\
(0.0444)\end{array}$ & $\begin{array}{c}-0.0628 \\
(0.0462)\end{array}$ & $+/-$ \\
\hline GDP & $\begin{array}{c}0.0685 \\
(0.0444)\end{array}$ & $\begin{array}{c}0.0638 * * \\
(0.0282)\end{array}$ & & $\begin{array}{l}0.0631^{*} \\
(0.0308)\end{array}$ & $\begin{array}{c}0.0637 * * \\
(0.0296)\end{array}$ & $\begin{array}{c}0.0779 * * * \\
(0.0293)\end{array}$ & + \\
\hline INF & $\begin{array}{l}-0.0122 \\
(0.148)\end{array}$ & $\begin{array}{c}-0.0389 \\
(0.0936)\end{array}$ & & $\begin{array}{c}-0.00337 \\
(0.137)\end{array}$ & $\begin{array}{c}-0.0389 \\
(0.0981)\end{array}$ & $\begin{array}{c}-0.0646 \\
(0.0968)\end{array}$ & $+/-$ \\
\hline Constant & $\begin{array}{c}5.933 \\
(7.748)\end{array}$ & $\begin{array}{c}10.52 \\
(6.491)\end{array}$ & $\begin{array}{l}-18.60 \\
(10.50)\end{array}$ & $\begin{array}{c}10.94 \\
(7.247)\end{array}$ & $\begin{array}{c}10.57 \\
(6.800)\end{array}$ & $\begin{array}{l}13.52 * * \\
(6.620)\end{array}$ & \\
\hline No. obs. & 135 & 135 & 135 & 135 & 135 & 135 & \\
\hline R-squared & 0.506 & & 0.726 & 0.531 & & & \\
\hline $\begin{array}{c}\text { Number of } \\
\text { banks }\end{array}$ & & 15 & 15 & 15 & 15 & 15 & \\
\hline
\end{tabular}

Note: Standard errors in parentheses; The significant parameters are indicated as such with $* * *, * *, *$ indicate significance at $1 \%, 5 \%$ and $10 \%$ levels.

Source: authors calculations

Funding costs (FC) did not have a significant impact upon the banking profitability. The coefficient estimated in both equations is negative, according to the expectations, but statistically insignificant. Our results are similar with those obtained by Dietrich and Wanzenried (2010) with reference to the profitability expressed by ROAE. In the Romanian banks is worth noting that in the pre-crisis amid accelerated dynamics of loans, the ratio of interest expenses to total deposits declined. Since 2007, in order to attract resources, amid costlier external financing, Romanian banks have proceeded to higher interest rates on deposits. Since 2009, the ratio of interest expenses to total deposits declined, on the one hand because the banks failed to attract sufficient liquidity to depositors, on the other hand as a result of the central bank's monetary policy, reflected in progressively lowering the monetary policy rate.

In the case of the income diversification of bank (NIIR) variable, the empirical results reflect a statistically insignificant rapport, but the coefficient is negative in both equations, opposing our expectations. However, the results are explained. Thus, the profitability of the studied Romanian 
banks depended in great measure on the interest income, and the earnings other than interest did not have an important impact upon the banking profitability.

Empirical results of panel regression for ROAE

\begin{tabular}{|c|c|c|c|c|c|c|c|}
\hline Variables & $\begin{array}{c}\text { (1) } \\
\text { ROAE }\end{array}$ & $\begin{array}{c}(2) \\
\text { ROAE }\end{array}$ & $\begin{array}{c}\text { (3) } \\
\text { ROAE }\end{array}$ & $\begin{array}{c}(4) \\
\text { ROAE }\end{array}$ & $\begin{array}{c}\text { (5) } \\
\text { ROAE }\end{array}$ & $\begin{array}{c}(6) \\
\text { ROAE }\end{array}$ & $\begin{array}{l}\text { Expected } \\
\text { sign }\end{array}$ \\
\hline & OLS & $\begin{array}{c}\text { Population } \\
\text { average } \\
\text { estimator, } \\
\text { robust }\end{array}$ & $\begin{array}{c}\text { Between } \\
\text { estimator }\end{array}$ & $\begin{array}{c}\text { Fixed } \\
\text { effects, } \\
\text { robust }\end{array}$ & $\begin{array}{c}\text { GLS } \\
\text { Random } \\
\text { Effect }\end{array}$ & $\begin{array}{c}\text { GLS with } \\
\text { AR, RE }\end{array}$ & \\
\hline EA & $\begin{array}{l}2.540 * * \\
(1.164)\end{array}$ & $\begin{array}{l}2.325 * * \\
(1.168)\end{array}$ & $\begin{array}{c}3.403 \\
(6.850)\end{array}$ & $\begin{array}{l}2.298 * \\
(1.132)\end{array}$ & $\begin{array}{l}2.321^{*} \\
(1.219)\end{array}$ & $\begin{array}{c}0.0414 \\
(0.0399)\end{array}$ & $+/-$ \\
\hline NPL & $\begin{array}{c}-2.379 * * \\
(0.975)\end{array}$ & $\begin{array}{c}-2.387 * * \\
(0.973)\end{array}$ & $\begin{array}{l}-3.244 \\
(1.840)\end{array}$ & $\begin{array}{c}-2.404 * * \\
(0.879)\end{array}$ & $\begin{array}{c}-2.388^{* *} \\
(1.015)\end{array}$ & $\begin{array}{c}-0.0874 * * * \\
(0.0236)\end{array}$ & - \\
\hline NIEA & $\begin{array}{l}-3.376 \\
(2.291)\end{array}$ & $\begin{array}{l}-6.641 \\
(4.466)\end{array}$ & $\begin{array}{l}0.0831 \\
(4.037)\end{array}$ & $\begin{array}{l}-7.778 \\
(4.950)\end{array}$ & $\begin{array}{l}-6.716 \\
(4.715)\end{array}$ & $\begin{array}{c}-0.327 * * \\
(0.130)\end{array}$ & - \\
\hline LA & $\begin{array}{l}0.0865 \\
(0.147)\end{array}$ & $\begin{array}{l}0.0421 \\
(0.190)\end{array}$ & $\begin{array}{c}0.162 \\
(0.903)\end{array}$ & $\begin{array}{l}0.0237 \\
(0.248)\end{array}$ & $\begin{array}{l}0.0417 \\
(0.201)\end{array}$ & $\begin{array}{l}-0.00554 \\
(0.0172)\end{array}$ & $+/-$ \\
\hline LIQA & $\begin{array}{c}-0.0924 \\
(0.180)\end{array}$ & $\begin{array}{c}-0.227 \\
(0.192)\end{array}$ & $\begin{array}{c}0.563 \\
(0.916)\end{array}$ & $\begin{array}{c}-0.333 \\
(0.250)\end{array}$ & $\begin{array}{c}-0.230 \\
(0.203)\end{array}$ & $\begin{array}{c}-0.0280 * * * \\
(0.0103)\end{array}$ & - \\
\hline $\mathrm{FC}$ & $\begin{array}{l}-1.238 \\
(1.210)\end{array}$ & $\begin{array}{l}-0.754 \\
(0.631)\end{array}$ & $\begin{array}{c}5.067 \\
(9.485)\end{array}$ & $\begin{array}{l}-0.455 \\
(0.806)\end{array}$ & $\begin{array}{l}-0.738 \\
(0.662)\end{array}$ & $\begin{array}{l}-0.0295 \\
(0.0547)\end{array}$ & - \\
\hline NIIR & $\begin{array}{l}-0.0606 \\
(0.255) \\
\end{array}$ & $\begin{array}{l}-0.279 \\
(0.292) \\
\end{array}$ & $\begin{array}{c}0.759 \\
(0.980) \\
\end{array}$ & $\begin{array}{l}-0.367 \\
(0.378) \\
\end{array}$ & $\begin{array}{l}-0.284 \\
(0.309) \\
\end{array}$ & $\begin{array}{l}-0.0141 \\
(0.0116) \\
\end{array}$ & + \\
\hline LNTA & $\begin{array}{c}7.872 * * * \\
(1.952) \\
\end{array}$ & $\begin{array}{l}8.109 * \\
(4.852) \\
\end{array}$ & $\begin{array}{r}18.19 \\
(10.59) \\
\end{array}$ & $\begin{array}{l}16.90 * \\
(8.883) \\
\end{array}$ & $\begin{array}{r}8.231 \\
(5.151) \\
\end{array}$ & $\begin{array}{r}0.345 \\
(0.283) \\
\end{array}$ & $+/-$ \\
\hline CR5 & $\begin{array}{l}-1.371 \\
(1.059) \\
\end{array}$ & $\begin{array}{l}-1.748^{*} \\
(0.893) \\
\end{array}$ & & $\begin{array}{c}-2.498 * * \\
(1.010) \\
\end{array}$ & $\begin{array}{l}-1.767^{*} \\
(0.936) \\
\end{array}$ & $\begin{array}{l}-0.129 * \\
(0.0667) \\
\end{array}$ & $+/-$ \\
\hline MKCGDP & $\begin{array}{c}-0.437 \\
(1.605)\end{array}$ & $\begin{array}{l}-0.0688 \\
(0.756)\end{array}$ & & $\begin{array}{c}0.579 \\
(1.115)\end{array}$ & $\begin{array}{l}-0.0537 \\
(0.796)\end{array}$ & $\begin{array}{c}-0.0628 \\
(0.0462)\end{array}$ & $+/-$ \\
\hline GDP & $\begin{array}{c}0.585 \\
(0.760)\end{array}$ & $\begin{array}{l}0.593 * \\
(0.360)\end{array}$ & & $\begin{array}{c}0.570 \\
(0.390)\end{array}$ & $\begin{array}{c}0.593 \\
(0.376)\end{array}$ & $\begin{array}{c}0.0779 * * * \\
(0.0293)\end{array}$ & + \\
\hline INF & $\begin{array}{l}0.0987 \\
(2.338)\end{array}$ & $\begin{array}{c}0.935 \\
(1.662)\end{array}$ & & $\begin{array}{c}2.924 \\
(2.910)\end{array}$ & $\begin{array}{c}0.974 \\
(1.757)\end{array}$ & $\begin{array}{l}-0.0646 \\
(0.0968)\end{array}$ & $+/-$ \\
\hline Constant & $\begin{array}{r}68.79 \\
(90.85) \\
\end{array}$ & $\begin{array}{r}117.2 \\
(77.14) \\
\end{array}$ & $\begin{array}{r}-258.2 \\
(193.2) \\
\end{array}$ & $\begin{array}{r}88.18 \\
(82.24) \\
\end{array}$ & $\begin{array}{r}117.8 \\
(80.54) \\
\end{array}$ & $\begin{array}{c}13.52 * * \\
(6.620) \\
\end{array}$ & \\
\hline No. obs. & 135 & 135 & 135 & 135 & 135 & 135 & \\
\hline R-squared & 0.491 & & 0.665 & 0.541 & & & \\
\hline $\begin{array}{c}\text { Number of } \\
\text { banks }\end{array}$ & & 15 & 15 & 15 & 15 & 15 & \\
\hline
\end{tabular}

Note: Standard errors in parentheses; The significant parameters are indicated as such with ***, **, * indicate significance at $1 \%, 5 \%$ and $10 \%$ levels.

Source: authors calculations

The coefficient of the bank size indicates a positive impact upon the profitability, in accordance to the results obtained by Pasiouras and Kosmidou (2007), Dietrich and Wanzenried (2010), but the rapport is not statistically significant, in both profitability equations. The positive coefficient indicates the fact that the banks recorded an increased level of diversification of the banking products, with positive impact upon the profitability. But, during the crisis, numerous banks made important loan loss provisions, so, overall, the impact of the bank's dimension is insignificant.

Regarding the 5-bank concentration ratio (CR5) variable, the empirical results show a statistically significant relationship at $10 \%$ significance level. In both equations, the coefficient indicates, as expected, a negative rapport with the banking profitability. Our findings are in line with those of Athanasoglou et al. (2008), but in contrast with those of Pasiouras and Kosmidou 
(2007) and Trujillo-Ponce (2013) who found a positive rapport. Dietrich and Wanzenried (2010) showed a negative relationship, but statistically insignificant. Our findings are explained by the fact that, in the recent years, the banking concentration level dropped amid increasing competition, with positive impact upon the profitability.

The ratio stock market capitalization to GDP (MKCGDP) variable did not have a significant impact upon the banking profitability, and the sign of the coefficient indicates a negative relationship with the banking profitability, according to our expectations. Our findings are in contradiction with those obtained by Naceur (2003), Pasiouras and Kosmidou (2007), Dietrich and Wanzenried (2010), but are explained by the fact that amid the increasing stock market capitalization in Romania, the banks reacted by reducing the interest rate margins, which lead to a decrease of the banking profitability.

The GDP variable is an important determinant of the profitability, in both equations, the coefficient being statistically significant at $1 \%$ significance level and in line with the expectations, indicates a positive rapport with the banking profitability. Our findings are in line with the conclusions of Mendes and Abreu (2003), Pasiouras and Kosmidou (2007), Sufian and Noor (2012), Trujillo-Ponce (2013). International crisis, deteriorating domestic and international economic environment, declining growth have, naturally, a significant negative impact on the profitability of Romanian banks.

In the case of the inflation rate variable, the coefficients are statistically insignificant in both profitability expressing equations. As mentioned before, the effects of the inflation upon the bank's profitability depend on the capacity of the bank management to forecast the inflation. Our findings reflect, in accordance with the theory that at the level of the banks analyzed, the inflation is not anticipated, so the effect of the inflation upon the banking profitability is rather negative, than important.

\section{Concluding remarks}

Our paper aimed to investigate the impact of some factors specific to banks, banking industry and macro-economic upon the profitability for a sample of 15 commercial banks that operate in Romania.

The empirical results of our study highlight the fact that the ratio of nonperforming loans, the management quality and the ratio of liquid assets to total assets has a significant impact upon the banking profitability. Instead, other factors, respectively the ratio of total equity to total asset, the ratio of loans to total assets, funding costs and income diversification of bank did not have an important effect upon the profitability. Regarding the four external independent variables used in our study, only the banking concentration and GDP had a significant impact upon the banking profitability.

Most of the results of our study are in line with the ones obtained in other studies that focused on banking profitability.

Based on the obtained results, we consider that the Romanian banks can improve their profitability, especially by increasing the quality of the assets, improving the quality of the management, increasing the non-interest income and increasing the bank dimension.

As future research directions, we intend to improve the results of our study by taking into consideration other explanatory variables for the banking profitability, such as: interest rates, taxation, exchange rates or financial liberalization.

\section{Acknowledgment}

With the support of the Lifelong Learning Program of the European Union through the Jean Monnet Module "Euro and the Banking Integration Process in an Enlarged EU - 2012-2911" this publication reflects only the authors' points of view and the Commission cannot be held responsible for any use which may be made of the information contained therein. 


\section{References}

1. Acaravci S.K., Calim A. E., 2013. Turkish Banking Sector's Profitability Factors. International Journal of Economics and Financial Issues. Vol. 3, No. 1, pp. 27 - 41.

2. Allison P., 2012, When Can You Safely Ignore Multicollinearity? September 10, available at http://www.statisticalhorizons.com/multicollinearity

3. Athanasoglou P., Delis M., Staikouras C., 2006. Determinants of Banking Profitability in the South Eastern European Region. Bank of Greece Working Paper No. 47.

4. Athanasoglou P.P., Brissimis S.N., Delis M.D., 2008. Bank-Specific, Industry-Specific and Macroeconomic Determinants of Bank Profitability. Journal of International Financial Markets, Institutions and Money, Vol. 18, No. 2, pp. 121-136.

5. Baltagi B.H., 2005. Econometric Analysis of Panel Data. 3rd Edition, John Wiley \& Sons.

6. Demirgüç-Kunt A., Huizinga H., 2000. Financial structure and bank profitability. The World Bank, Policy Research Working Paper 2430.

7. Demirgüç-Kunt A., Huizinga H., 1998. Determinants of Commercial Bank Interest Margins and Profitability: Some International Evidence. The World Bank, Policy Research Working Paper 1900.

8. Dietrich A., Wanzenried G., 2010. Determinants of Bank Profitability Before and During the Crisis: Evidence from Switzerland, available on-line at SSRN: http://ssrn.com/abstract=1370245

9. Goddard J., Molyneux P., Wilson J.O.S., 2004. The profitability of European banks: a cross-sectional and dynamic panel analysis. Manchester School, Vol. 72, No. 3, pp. 363381.

10. Gujarati D., 2004. Basic Econometrics. Fourth Edition, The McGraw-Hill, New York.

11. Mendes V., Abreu M., 2003. Do macro-financial variables matter for european bank interest margins and profitability?. $2^{\text {nd }}$ CIEF Workshop European Integration and Banking Efficiency, Lisbon, 30-31 October 2003.

12. Naceur S.B., 2003. The determinants of the Tunisian banking industry profitability: panel evidence, Paper presented at the Economic Research Forum (ERF) 10th Annual Conference, Marrakesh-Morocco, 16-18 December.

13. O'Brien R. M., 2007. A Caution Regarding Rules of Thumb for Variance Inflation Factors, Quality \& Quantity, no. 41, pp. 673-690

14. Pasiouras F., Kosmidou K., 2007. Factors influencing the profitability of domestic and foreign commercial banks in the European Union. Research in International Business and Finance, Vol. 21, No. 2, pp. 222-237.

15. Socol A., 2011. Loan losses provisioning processes in Romanian banks during January 2007 - February 2011. Annales Universitatis Apulensis, Series Oeconomica, No. 13 (1), pp. 106-112.

16. Staikouras C.K., Mamatzakis E., Koutsomanoli-Filippaki A., 2007. Operating Performance of the Banking Industry: an Empirical Investigation of the South Eastern European Region. South-Eastern Europe Journal of Economics, Vol. 5, No. 2, pp. 245-266.

17. Sufian F., 2010. Financial depression and the profitability of the banking sector of the republic of Korea: panel evidence on bank-specific and macroeconomic determinants. AsiaPacific Development Journal, Vol. 17, No. 2, pp. 65- 92.

18. Sufian F., Noor M.A., 2012. Determinants of Bank Performance in a Developing Economy: Does Bank Origins Matters?. Global Business Review, Vol. 13, No. 1, pp. 1-23

19. Trujillo-Ponce A., 2013. What determines the profitability of banks? Evidence from Spain. Accounting and Finance, Vol. 53, No. 2, pp. 561-586. 